\title{
AbILITy to PAy IN NEW ZEALAND'S TAX SYSTEM
}

\author{
Åsa Gunnarsson
}

This article begins with a review of tax distribution principles and theory to provide a framework to which the position and interpretation of the ability to pay principle can be related. In the next three sections I describe how the income tax base, the wealth tax and the income support system correspond with the ability to pay principle. Finally, I look upon new equity trends in taxation from a New Zealand perspective.

\section{STRUCTURES AND PRINCIPLES}

The reforms of the eighties and the beginning of the nineties among the OECD countries have been based on similar problems. The core of the problem was that the tax levels and the income tax structures were not in harmony. A progressive tax schedule, applied on a narrow tax base with a source dependent and source differentiated definition of income, was highly inefficient and distorting in the Paretian sense. The income tax structure was undermining itself. The solutions adopted can briefly be summarised: introduction of a comprehensive income tax base that, by definition, is very close to the Haig-Simons theoretical concept of income (net accretion of a spending unit's power to consume over some period of time, without distinctions as to source or use); a change in the mix of tax bases with a move from income tax towards consumption tax; the flattening of the income tax rates schedules or/and reduction in the number of tax brackets. ${ }^{1}$

These tax reforms, far reaching as they are in structural aspects, reflect changes in basic attitudes to tax policy, with corresponding changes in the level of principle. Horizontal fairness and tax neutrality have dominated at the cost of vertical equity and redistributive

- Dr Åsa Gunnarsson is a senior lecturer at the Department of Legal Science, University of Umeå, Sweden. The article is a result of an academic year as visiting fellow at the Law Faculty, Victoria University of Wellington, Te Kauhanganui Tatai Ture, Te Whare Wananga o te Upoko o te Ika a Maui. The author wishes to thank Professor John Prebble for good support during the year, and lecturer Sandra Petersson for detailed comments and valuable suggestions.

1 K Messere, Tax Policy in OECD Countries: Choices and Conflicts, (IBFD Publications BV, Amsterdam, 1993), 30-32, 38. 
elements in taxation. The conflict between the requirement of vertical equity and economic efficiency that for a long time has been presumed and predicted in theory is now confirmed in practice by the loss of vertical equity in the income tax structure and in the mix of tax bases. ${ }^{2}$ Changes in the position of different types of tax principles are of course not a new phenomenon. Such changes are expected in the legislative process of liberal democracies in a dynamically changing world. With respect to the pluralism of tax forms, pluralism may also be found with respect to fundamental principles of taxation. The different types of conflicting objectives that have emerged during the last period of tax reforms are in many ways connected to old and always ongoing basic issues of taxation.

At the most general level one finds the perennial conflict between the fundamental function of taxation, to provide revenue to finance public expenditures, and economic and social policy objectives that tend to reduce revenue collections. A principle issue of the same dimension and of the same importance over time is the distribution of the tax burden. The normative elements for distribution of the tax burden are horizontal and vertical equity, neutrality, and redistribution. These standards are in turn parts of a broad political, philosophical and economical context in both theory and practice. As society and theories have changed, the normative foundations of how to distribute the tax burden also have changed over time.

Equitable distribution, vertical or horizontal, is by definition related to the principles of ability, sacrifice, and benefit, and it reflects the need to justify taxation in the relation between state and citizen. Redistribution emerges from the use of taxation as an instrument for welfare policy. Neutrality is based on adjusting taxation to what is understood as an efficient allocation of resources in the market economy. Concepts of distributive justice and efficient allocation of resources represent different aspects of the function of public finance. These concepts may in certain cases even be conflicting.

In tax legislation, the concrete application of theoretical principles of equity, redistribution and neutrality takes place through applying principles of law on the basis of ethical, economical and political values and objectives. These fundamental principles of law therefore act as a meeting point between basic values and objectives of the legislation on the one hand, and the legal rules formed by statutes and case law on the other hand.

Whatever the choice of distributive principles, the choice must be based on theoretical and practical tax reform analysis to guide the structural changes in the way intended. The interpretation and implementation of principles must be clear and open so normative coherence can be achieved in the tax system in its entirety. The use of principles as a mere legitimising front creates instability. The equity principles support the justification of the

2 Above n1, 33-34, and Åsa Gunnarsson Skatterättvisa (Iustus, Uppsala, 1995) 283-289. 
tax legislation. This is a fundamental issue that no tax legislator in the world can ever get around.

\section{A The Principles of Equity}

The main contours of the different schools of tax theory are relatively easy to discern. This may be due to the fact that the number of original theoretical solutions to the distribution problem is limited. Most solutions are simply variations on the same theme. Principles of distribution can be related to different historic periods and today some may be found obsolete or of historic interest only. Normally, however, the basic theme has permanent validity, whereas the variations lose relevance with the change of political climate.

The individualistic concept of the state comprises different forms of liberalism and utilitarianism. A characteristic of liberalism is that the similarity of taxation to a voluntary exchange transaction is taken as a basis for an equitable distribution of a tax burden given as a function of fiscal concerns. An equitable exchange between state and individual is expected. The benefit principle is given a concrete form in the Lindahl solution that defines the willingness to pay for public services in a way similar to the market pricing of goods and services. A decisive factor in the willingness of the individual taxpayer to pay in weighing private against public consumption is that the marginal tax for each individual citizen must not exceed his or her marginal benefit from the government expenditure, estimated in money terms. ${ }^{3}$

The sacrifice theory developed in the utilitarian world of ideas. Its main tenet is that it is a sacrifice for the individual to pay tax. The tax burden should imply equal subjective sacrifice for the individual. A subjective sacrifice is established according to a common marginal utility curve derived from the decreasing utility of income. The principle of equality in proportional sacrifice opens up for both a horizontal and a vertical interpretation; the minimum sacrifice principle based on equality in marginal sacrifice leads to a vertical concept of equity. ${ }^{4}$

The theory of ability to pay originally emerged from the philosophical idea of the state as a social organism in which there exists a mutual dependency between state and individual. Later, the theory of ability to pay has been taken as a basis for the welfare state view on the distribution of the tax burden. It is a position of strong general validity that the concept of ability to pay is the best expression of the ethical idea of distributive equity in tax law. There are two theoretical interpretations of the theory of ability to pay. One is an equality-

3 Above n 2, 96-97, 99-104.

4 Above n2, 108-115. 
oriented interpretation, implying horizontal equality of treatment, in line with the possible interpretation of the principle of equal sacrifice. The other is an interpretation oriented towards the welfare state, using the concept of ability to pay for the purpose of levelling incomes and net wealth. Regardless of the approach chosen, the measurement of the individual taxpaying capacity should be equal to the amount or degree of private needs satisfaction that the taxpaying citizen can achieve. This position of needs satisfaction can, in turn, be measured in two different ways. One is to compute the satisfaction of needs from the origin side; the other makes the calculation on the usage side. The measurement of the individual's capacity to pay can, accordingly, comprise different acquisitions of means or resources, such as cash income, yield, benefits, and wealth. The taxpaying capacity can also be measured by consumption of goods and services. Regardless of which approach is chosen, the calculation of taxpaying capacity should also be limited to individual capacity in order to target circumstances limiting the individual satisfaction of needs in relation to the economic capacity. In tax theory, it is generally felt that income is practically the best indicator of what represents a person's opportunities for private needs satisfaction. The best method of assessing the real satisfaction of needs, however, is to measure the individual's consumption of monetary and other resources. ${ }^{5}$

The interventionist function of the welfare state is most strongly reflected in the social policy tax theory. Principles of social policy and progression aim to use taxation for equalisation through redistribution of economic resources. The redistribution objective of taxation has been motivated in different ways. Wagner built on the same hypothesis as the marginal utility theory, namely that the subjective utility decreases for every utility unit acquired. He used marginal utility to establish an objective reason for the justification of progressive taxation. Another such reason is that the ability to pay tax increases in a higher proportion than the increase in income. The wealthier one is, the easier it is to increase one's income. A third point of departure is the choice of equality as the ethical foundation for taxation. ${ }^{6}$

\section{B The Principles of Neutrality}

Tax neutrality implies that the distribution of the tax burden should be neutral in relation to economic behaviour and that, for this reason, taxation should be noninterventionist. When discussing the distorting effects of taxes, one should be aware that the concept of neutrality can be understood in different ways, depending on the level at which it is applied and to what it is related. Neutrality principles of tax law must, therefore, be related to the economic policy objective behind them. Neutrality with respect to the

5 Above n 2, 115-124.

6 Above n 2, 127-134. 
allocation of production factors and the principle of competitive neutrality are two principles of tax neutrality which are related to the neo-classical economic policy objectives of a tax system. The first principle is directed towards preventing taxation from impeding economic growth. This principle favours a low tax rate and the avoidance of interventionist taxation in all areas. The other principle expresses the policy objectives of not impeding free competition. Competitive neutrality is one of several conceivable partial neutrality relationships with respect to economic actions. Competitive neutrality can, in turn, be broken down into several aspects. Regardless of competitive relationships, the general interpretation of the principle is that alternatives that are economically of equal value should not be rendered unequal by taxation. ${ }^{\text {? }}$

\section{Domination and Universality of Principles}

The great difference between the equity principles is that the basis for the distribution of tax burden according to the benefit principle, the principle of equality in proportional sacrifice and the ability principle, as opposed to the minimum sacrifice principle as well as the principles of social policy and progression, leads to a horizontal concept of equity. Individuals with equal taxable capacity or equal interest in collective goods should pay the same amount in tax. The approaches of both the minimum sacrifice principle and the social policy oriented principles, in contrast, lead to a vertical concept of equity. For different reasons, individuals with high taxable capacity should be taxed relatively higher than those with low taxable capacity. It is common to interpret the ability principle in this way too, but a diminishing utility approach on the individual taxpaying capacity is questionable.

What can be stated after examining different tax theories is that there is no objective basis for establishing what is an equitable distribution of the tax burden. One cannot use the theory of marginal utility or any theoretical model to establish such an objective foundation. In contrast, the legislator, by taking a position on a matter of legal policy, can decide what should be the basic, ethical norm for an equitable taxation of the income, consumption, or net wealth of individuals. In a pluralistic tax system, where income, consumption, and net wealth form the tax bases for different types of tax, the legislator may choose to justify each form of tax by using different ethical arguments. If taxation has to be neutral with respect to economic actions, it is up to the legislator to choose which economic policy objective or objectives should form the basis of a neutral distribution of the tax burden.

Even though the dominance of some principles cannot be consistently delimited and allocated to definite periods in time, one can still state that the idea of voluntarism in 
taxation and equivalence between the tax payment by the individual and its counterpart in public performance do not constitute a rational basis for the tax system in the welfare state. This idea has therefore been replaced by mandatory taxation in which the principle of ability to pay is seen to be the best expression of the ethical idea of distributive equity in tax law. That the benefit theory has never been allowed to dominate the practical formulation of the tax law does not mean that it is entirely irrelevant. The conflict over how far the tax system should reflect the taxpayer's ability to pay and how much it should regard the benefits the taxpayer receives is always there. What should be stressed here is that one theory of how to distribute the tax burden cannot replace all other theoretical frameworks. The theories of taxation offer different solutions to the question of what the basis for the distribution of the tax burden should be, but no single solution is universal. ${ }^{8}$

\section{How to Apply the Ability to Pay Principle}

As explained above, full normative coherence in relation to the principle of ability to pay requires that the total economic potential for the individual's needs satisfaction is included in the income tax base. Moreover, restrictions on the personal satisfaction of needs, relevant to the ability to pay tax, must be taken into account. This involves three elements. The income tax base has to be broad. Reduced ability to pay caused by high maintenance costs must be taken into account, as well as the use of the individual as the tax unit. The question of tax rates in relation to the ability to pay principle depends entirely on how these three elements are composed. ${ }^{9}$

The trend towards successive broadening of the income tax base based on the HaigSimons concept of income is therefore in line with the view that income is what establishes a person's ability to pay tax. But at the same time it is also important to bear in mind that full adherence to the ability principle demands that the income tax structure consider circumstances that reduce the ability to pay through instruments like deductions or tax credits. The individual is the preferred unit for measuring observed income representing the capacity to pay. In contrast, using the marital unit increases the potential for errors, as the unit's true ability to pay will in part depend upon the correlation between the primary

$8 \quad$ Above n 2, 277.

y See for example M J Boskin, "Factor Supply and Relationship among Choice of Tax Base, Tax Rates and the Unit of Account in the Design of an Optimal Tax System", in HJ Aaron and M J Boskin (eds), The Economics of Taxation, (Brookings Institution Washington, 1980). 
earner's capacity to earn and the number of hours the secondary earner works. ${ }^{10}$ The marital tax unit is therefore seen as a defective indicator of ability to pay. ${ }^{11}$

The equality-oriented interpretation of ability to pay, which has received increasing attention in the tax reform movements of the 1980s and 1990s and among a majority of tax analysts, unanimously supports the full taxation of capital gains. With the Haig-Simons concept of income, horizontal equity will be seriously violated if capital gains are not fully taxed. Differences in the form of income earned and investment opportunities will be reflected in the distribution of the tax burden. Taxpayers with the same economic incomes face the risk of unequal tax treatment. ${ }^{12}$

Global taxation, where all income from whatever source is aggregated and one rate schedule is applied, is consistent with the ability principle. A contrasting structure is the schedular taxation under which each source of income is subject to separate treatment for rate and base. Differentiated tax on different tax objects means that the calculation of tax is removed both from the tax subject and from a unitary assessment of the ability to pay tax. This is in conflict with the core of the principle of ability to pay, namely, a subject-related ability to perform. The whole idea of a direct income tax as the dominating tax form rests on this fundamental assumption. The real effect of the schedular income tax system is to leave the subject-related principle of equal treatment of equal and instead focus on the equal treatment of equal type of tax object.

Using the ability to pay as the one and only normative foundation for progressive income taxation or for a net wealth tax, without adding any further component to the definition of ability to pay tax, is a very questionable approach. In order to motivate a progressive tax, the concept of ability to pay must also include a postulate of diminishing marginal benefit, or some similar argument, that attaches a relatively higher ability to pay to higher incomes than it does to lower ones. This is, of course, perfectly possible as long as it is assumed that the postulate builds on tax policy value judgements and one does not erroneously adopt an obsolete scientific view that promotes the postulate to the level of an economic law of nature. Ability to pay can justify a net wealth tax if net wealth is regarded as a measurement of ability to pay, independent of income. Funded income offers more economic safety and hence more ability to pay than non funded income. Disregarding the

10 P Apps, "Tax Reform and the Tax Unit" (1984) 1 Australian Tax Forum, 472, and J Grbich, "The Tax Unit Debate: Notes on the Critical Resources of a Feminist Revenue Law Scholarship" (199091), Canadian Journal of Women and the Law, 512-514.

11 W Chan, "Taxing the Female - as Woman or Wife?", in C Scott (ed), Women and Taxation (Institute of Policy Studies, Victoria University of Wellington, 1993), 64-65.

12 R Krever and N Brooks, A Capital Gains Tax for New Zealand, (Victoria University Press, Wellington, 1990), 41-44. 
fund theory, net wealth can only represent an independent measurement of ability to pay, if the income and consumption tax bases are limited, and if there is no death or gift duty. This allows for the presumption that net wealth to some extent conveys unused economic capacity.

\section{INCOME TAX BASE}

The existing New Zealand income tax base includes wages and salaries ${ }^{13}$, business profits ${ }^{14}$, returns from assets such as rental income, interest, dividends ${ }^{15}$, as well as some realised gains. ${ }^{16}$ There are two major gaps in the coverage of the New Zealand personal tax base which are not consistent with the ability to pay principle. First, the base does not generally include increases in the market value of assets and imputed income from those assets unless capital gains are realised in the ordinary course of business. Secondly, fringe benefits are excluded from the personal tax base and instead taxed separately, levied on the employers. $^{17}$

Income is not defined in the Income Tax Act, but the courts have, in general, accepted that income is not a term of art and has to be examined in accordance with ordinary concepts and usages of people. ${ }^{18}$ Examination in accordance with ordinary concepts has been transformed into statutes. ${ }^{19}$ At a first glance this could be seen as a very generous approach leading to a very broad definition of income. However, like the courts in all other Commonwealth countries, the New Zealand courts have chosen to restrict the definition of income by excluding capital gains. ${ }^{20}$ Gains of capital nature are not income according to ordinary concepts. ${ }^{21}$

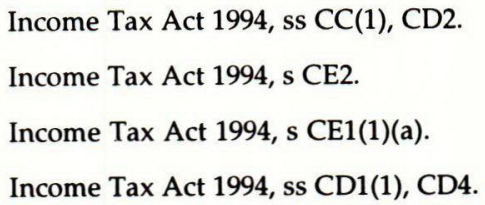
tax. To what extent the employer carries the economic burden depends on the relation between the sensitivity of the employers' demand for labour when labour costs increase and the employees' supply of labour with respect to changes in their real after-tax income. Even so, the structure of levying the tax on the employer is of significant importance when the issue is to determine the fulfilment of the ability to pay principle, which will be developed later.

8 Scott $v$ CT (1935) SR (NSW) 215, 219.

Income Tax Act 1994, s CD5.

Above n 12, 36.

See for example Burnett's Motor Ltd v CIR (1977) 2 TRNZ 359, and J Prebble, Income Tax Law: Concepts and Cases (Butterworths Wellington, 1994), 235. 
In what has become a frequently applied definition of income for tax purposes, Justice Quilliam adopted counsel's submissions about the three principal features of income which had become recognised in the cases. ${ }^{22}$ The first was that income is something which comes in. ${ }^{23}$ The second was that income imports the notion of periodicity, recurrence and regularity. ${ }^{24}$ And the third was that whether or not a particular receipt is income depends upon its quality in the hands of the recipient. ${ }^{25}$ These characteristics of income do not take into account the extent to which a particular receipt is income in terms of adding to an individual's wealth. ${ }^{26}$ That is the typical case with capital gains which often are not realised annually.

\section{A Income $v$ Capital}

The important distinction between ordinary income and capital gains is far from clear as they are not defined in the Income Tax Act. Income from capital falls mainly into one of three categories: ordinary income, which is capital income interpreted under ordinary concepts over the years by judges; income derived from the holding or disposition of an identifiable asset (income on capital account), which traditionally has not been taxable other than in the course of business; and income on capital account which is made taxable by explicit provisions in the Income Tax Act, ${ }^{27}$ provisions dealing with certain land transactions, ${ }^{28}$ certain sales of personal properties ${ }^{29}$, investment income, ${ }^{30}$ and commercial bills. $^{31}$

Except in cases containing such express inclusions, the courts rely on the assumption that only income, and not capital, is taxed. Relying on such an assumption places a difficult task before the courts. Different analogies and statements have been made by the courts to

22 Reid v Commissioner of Inland Revenue [1983] 6 NZTC 61,624.

23 Tennant $v$ Smith [1892] AC 150.

24 FC of T v Dixon (1952) 86 CLR 540, 567-568.

25 Scott $v$ FC of $T$ (1966) 117 CLR 514, 526.

26 New Zealand Government Consultative Document on the Taxation of Income from Capital. (Government Printer, Wellington, 1989), 14.

27 Above n 26, 18.

28 Income Tax Act 1994, s CD 1.

29 Income Tax Act 1994, S CD 4.

30) Income Tax Act 1994, s CE 1.

31 Income Tax Act 1994, s CE 3. 
draw a line between the two concepts. ${ }^{32}$ One of them is the old, well known distinction between the fruit and the tree; capital is compared to the tree and income to the crop. The tree is described as "a reservoir supplied from springs", while the fruit as "the outlet stream, to be measured by its flow during a period of time." ${ }^{.33}$ Traditionally this analogy has been interpreted to immunise capital gains against income taxation. Capital gains are inseparable from the underlying capital assets, and therefore cannot constitute income. Krever is one of those who criticises this traditional distinction of the case. His position is that both income and capital gains constitute income for income tax purposes. The radical conclusion is that expanding the income tax base to embrace capital gains is in line with the United States Supreme Court decision in Eisner v Macomber. ${ }^{34}$

As already noted, among tax analysts and legislators around the world the support for full taxation of capital gains is almost unanimous. Contradictory opinions concern the questions how and when capital gains should be taxed, not if they should be taxed. Should capital gains be treated as ordinary income or be given some preferential treatment? Should they be taxed when realised or as they accrue? The same support is given by several major inquiries in New Zealand.

The first report in 1967, the Ross Committee recommended, with the reservations of moderate tax rates and the implementation of the proposed income tax package in its entirety, that realised capital gains be included in the income tax base. The Ross Committee based its recommendation on grounds of equity, including both the aspect of horizontal equity as well as the ability to pay. The Ross Committee also emphasised that the "absence of a capital gains tax tends to encourage the holding of assets for speculative purposes rather than for productive purposes." Furthermore, it noted that if tax rates were lowered, as it had recommended, then the tax base would necessarily have to be broadened to include capital gains. $^{35}$

In 1982, the opposite position was presented by the so called McCaw Committee, appointed by the Muldoon Government. The McCaw Committee stated that it was "not convinced of the need for a separate capital gains tax...even though capital gains are being made by some which should in principle be taxed. The adoption of the suggestions

32 F Owen The Tax Practitioner 1997 (Butterworths Wellington, 1997), 7-9.

33 The metaphor derives from a decision of the United States Supreme Court, Eisner $v$ Macomber, (1920) 252 U.S. 189.

$34 \quad$ R Krever "The Ironic Australian Legacy of Eisner $v$ Macomber" (1990) 7 Australian Tax Forum, 191206.

35 Report of the Taxation Review Committee Taxation in New Zealand (Government Printer Wellington, 1967), 18, 405-409. 
concerning determination of business income would substantially meet equity requirements. ${ }^{136}$ The basic arguments presented against a capital gains tax were that it would yield little revenue. The small amount of revenue would not justify the substantial complexity which provisions of capital gains would bring into the tax system. The McCaw Committee also concluded that "the introduction of capital gains in a period of high inflation would probably bring with it more inequities than it would cure, unless the effects of inflation were also taken into account." ${ }^{37 "}$

After 1982, several tax analysts and committees have strongly recommended a comprehensive income tax base including capital gains. Some tax analysts are of the opinion that the failure to tax capital gains is a fundamental structural flaw in the New Zealand tax system. ${ }^{38}$ In 1987, a Committee charged to investigate a comprehensive tax reform admitted that tax theory produced strong arguments for making no distinction between income and capital on both the grounds of equity and economic neutrality. The Committee implied that, despite the theoretical, practical and political difficulties, the only satisfactory solution to the problem of taxing capital gains would be a comprehensive proposal. ${ }^{39}$

The Royal Commission on Social Policy, charged to assess how to make New Zealand a more fair and just society, also strongly recommended that capital gains be taxed. In assessing the use of the tax system to reduce disparities in income and wealth the Commission stated:"[v]iewed in terms of fairness (and economic efficiency) the argument for taxing capital gains is overwhelming. ${ }^{40}$

In the 1987 "Post Election Briefing", the incoming Government pointed out the considerable consequences of not including capital gains and losses in income. Difficulties in adequately taxing returns from investment in land, company shares, and unit trusts, reflect the exclusion of capital gains from the income tax base. Moreover, many avoidance schemes exploit the distinction between current and capital income. The Government 1985) 89, A Alston Tax Treatment of Capital Gains in New Zealand, (Victoria University Press Wellington, 1985) 17, and R Stephens "Radical Tax Reform in New Zealand" (1993) 14 Fiscal Studies, 61 .

39 Consultative Committee on Accrual Tax Treatment of Income and Expenditure Comprehensive Tax Reform and Possible Interim Solutions (Government Printer, Wellington, 1987), 4.

41) Royal Commission on Social Policy Working Papers on Income Maintenance Working Paper No 2 (Royal Commission on Social Policy Wellington, 1988), 59. 
planned to address the issue in the accrual regime and in the reform of the taxation of international income. ${ }^{41}$

The July 1988 Budget confirmed the Government's intention to introduce a capital gains tax or, more generally, to improve the system of taxing income from capital. This objective was pursued by the Labour Government with David Caygill as Minister of Finance, after Roger Douglas' departure from the Government. A Consultative Committee was set up and in December 1989, it presented its report. ${ }^{42}$ The document was the outcome of a comprehensive review of the then current tax treatment of income from capital. Its central focus was to identify the aspects of the current treatment that were seen as unfair and inefficient by the Minister of Finance. ${ }^{43}$

The Committee stated that the exemption of a wide range of "income on capital account" (including so-called "capital gains"), was largely a result of historical developments by the courts. The distinction between taxed and untaxed income was extremely difficult to draw and was not related to the way people view investment decisions or their own economic position. The original judicial distinction between ordinary income and capital income had therefore been considerably modified over a long period by specific statutory provisions that were narrowly focused and produced anomalies between different taxpayers and different types of transactions. Taxing some forms of income on capital account while leaving other forms untaxed merely shifts the boundary between taxed and untaxed income. This creates problems on the new boundary. The lack of adjustment for inflation in calculating taxable income was also a main problem pointed out by the Committee.

Concluding that the exemption of certain forms of income on capital account was a serious deficiency that undermined the fairness of the tax system, increased its costs and discouraged productive investments, the Committee proposed to remove most of the exemptions ${ }^{44}$ However, the commitment to improving the taxation of income from capital was shelved before the 1990 General Election. With Labour's, defeat the matter lapsed. ${ }^{45}$

41 New Zealand Treasury Government Management, Brief to the Incoming Government Vol I, (Treasury Wellington, 1988) 301-302.

42 C Sandford Successful Tax Reform, Lessons from an Analysis of Tax Reform in Six Countries (Fiscal Publications Wiltshire, 1993), 57-58.

43 New Zealand Government Consultative Document on the Taxation of Income from Capital (Wellington, 1989), preface I.

Above $n$ 43, 305-306.

Aboven 42, 58. 


\section{B Fringe Benefits}

The Haig-Simons definition of income as the net accretion of a spending unit's power to consume over some period of time, without distinctions as to source or use, includes both money, and anything that could be valued in terms of money. ${ }^{46}$ It is the increase or accretion of the taxpayer's power to satisfy his or her wants, the so called accretion principle, that should be included in the income tax base. The definition embraces all types of receipts, in cash or in kind. ${ }^{47}$ An important part of the employment remuneration system is the non monetary advantages provided to employees in addition to wages and salaries. If these fringe benefits are not subject to tax, there will be substantial economic distortions in the form of employee compensation. The share of remuneration in the form of untaxed fringe benefits will inevitable grow larger than the share of cash income leading to erosion of the income tax base. Obviously both horizontal and vertical equity will be violated. ${ }^{48}$

New Zealand introduced a quarterly Fringe Benefit Tax (FBT) in April 1985 to ensure that non-monetary forms of remuneration are subject to tax. However, it is the employer, who provides employees with benefits, who is liable for the FBT. The reasons for this change were mainly fiscal, higher revenue and lower administrative costs. ${ }^{49}$

An employer is defined as a person who pays "source deduction payments" (like salaries and wages, but also extra emoluments or a withholding tax payment). An employee is defined as a person who at any time, now, before or in the future, receives a source deduction payment. ${ }^{50}$ When first introduced, the FBT was $45 \%$ of the taxable value of fringe benefits. Today the rate is $49 \%$ and the FBT is deductible by the employer on an accrual basis, meaning that the effective rate is $33 \%$ for taxpayers, equivalent to the top personal tax rate. ${ }^{51}$

The New Zealand FBT identifies five main categories of taxable fringe benefit: the private use of motor vehicles; low interest loans; free and discounted goods and services; employer contributions to superannuation, sickness, accident and death benefit funds; and

46 R M Haig, "The Concept of Income - Economic and Legal Aspects" in R M Haig, (ed) The Federal Income Tax (New York, 1921), 7.

47 D J Collins "Taxation of Fringe Benefits - An Economist's Perspective" (1987) 4 Australian Tax Forum, 97-98.

48 C Scott "Taxing Fringe Benefits: The New Zealand and Australian Experience" in C Sandford (ed), Key Issues in Tax Reform (Fiscal Publications, Wiltshire, 1993) 22 and 35-36.

49 Above n 32, 21-22, and Above n 43, 36-38.

50 Income Tax Act 1994, s OB 1.

51 Income Tax Act 1994, s ED 2. Also above n 32, 21-12 and above n 48, 24. 
lump sum retiring allowances and some categories of redundancy payments. ${ }^{52}$ Even if the tax base covers most fringe benefits provided by employers to their employees, it is still not consistent with the ability to pay principle. By imposing the FBT on the employer, a large part of the individual's total potential for needs satisfaction is excluded from the personal income tax base. Both horizontal and vertical equity demand a tax structure based on subject-related ability to perform, which is what the concept of global taxation supplies. All income has to be calculated and imposed on the individual taxpayer, and one rate schedule applied. A split in the individual's tax capacity, such as the FBT, opens up the potential for unequal treatment of taxpayers in similar economic circumstances, particularly where more than one marginal tax rate exists. ${ }^{53}$

\section{The Tax Unit}

New Zealand's tax system has been largely designed around the individual as the unit of assessments, a fact that makes New Zealand unusual compared to most other OECD countries. Marriage or de facto relationship does not influence tax liabilities, except when couples have dependent children. Different types of tax credits for family support use the aggregate parental income to determine the size of the tax reduction. This means that the unit of assessment for income tax is, as a main rule, free from presumptions such as the dependency of women on their husbands' income or that married people are better able to pay tax because they are married rather than single. ${ }^{54}$

New Zealand's most comprehensive tax reform policy statement on the unit of taxation was the McCaw Report from 1982. The report recommended adopting a marital tax unit because, in the absence of joint filing of aggregate income, principles of tax equity were offended. At the horizontal level, family units of equal income were not taxed similarly, preferences being given to those family units with more than one earner. The Task Force saw the married couple as the appropriate tax unit because the inherent economies of living together increase a couple's welfare and its ability to pay. ${ }^{55}$ In the search for the ideal horizontal equity between couples, the McCaw Report came up with a proposal which would favour married couples with a considerable disparity in individual incomes over other taxpayers. Typically, disparity will be greater when the secondary income-earner does not work full-time, in which case there will already be error in the observation of

Income Tax Act 1994, s CI 1.

Above n 48, 36-38.

S St John "The Tax/Benefit Interface" in Scott above n 11, 135-136.

Above $\mathrm{n} 36,95$. 
ability to pay. Despite the recommendation in the McCaw Report, the legislative response has been to maintain the individual as the appropriate tax unit. ${ }^{56}$

\section{Tax on Wealth}

As described above, the ability to pay principle could hardly be used as a normative foundation to advocate a net wealth tax, unless the income tax base is limited, which is the case for New Zealand. New Zealand has no annual tax on the stock of wealth. No estate duty is payable on the estate of any person dying on or after 17 December 1992. The Estate Duty Abolition Act 1993 abolished estate duty by reducing the rate to nil. The legislation, however, remains in place. The only existing tax on wealth is a gift duty on wealth transfers. The Government at one stage announced its intention to repeal gift duty if appropriate measures could be found to avoid unlimited gifting as an instrument for tax planning, or to avoid abuse of targeted social welfare payments. This has not occurred and may never occur. ${ }^{57}$

Substantial exemptions meant that the majority of land in New Zealand remained outside the tax base, giving rise to distortions and unfairness in its application. The estate duty was as Sandford put it, a sorry spectacle, based on the wrong principles for a death duty. ${ }^{58}$ The Government faced the alternative of either broadening the base to include land currently exempt or abolishing the tax. ${ }^{59}$ The land tax issue in New Zealand demonstrates the interaction among political factors, property market forces, and tax system reform. When inflation, and a property boom produced by the global financial deregulation, tested the tax's political and economic viability, abolition not reform was the unexpected outcome. The New Zealand abolition of land tax is judged as an atypical response to the policy problem of dealing simultaneously with land taxation, inflation, and the taxation of capital gains; this approach is not likely to be repeated elsewhere. ${ }^{60}$

Without an annual wealth tax or inheritance-type of wealth transfer tax, or a comprehensive income tax base including capital gains, a large part of the net accretion of assets and imputed income from those assets will remain untaxed. This is an anomaly in a tax system based on the ability to pay principle. In order to achieve horizontal equity, Sandford has proposed the introduction of an annual wealth tax in New Zealand with

Chan, above $n 11,54,63$ and 65.

Above $n$ 32, 25-2.

C Sandford Taxing Wealth in New Zealand (The Institute of Policy Studies, Wellington, 1987), 48.

D Caygill Budget Announcements (New Zealand Government Wellington, 24 July 1990), 107.

B F Reece "The Abolition of Land Tax in New Zealand. Searching For Causes And Policy Lessons" (1993), 10 Australian Tax Forum, 242-244. 
moderate rates on a relatively broad base. He has also proposed a complementary accessions tax to replace the former estate and the present gift taxes with the intent to reduce inequalities in wealth-holding. ${ }^{61}$

\section{E Income Support Through the Tax System}

There have been different types of financial assistance available to families in New Zealand. A common objective throughout has either implicitly or expressly been the prevention of poverty, investment in children, and the horizontal redistribution of income. Measures implemented have included allowances, tax exemptions and rebates, minimum wages, and benefits. ${ }^{62}$ Presently the principal forms of assistance are family support, guaranteed minimum family income, childcare subsidy, domestic purposes benefit, widow's benefit, orphan's benefits, and unsupported child's benefit. ${ }^{63}$ The low income earner rebate (LIR) for New Zealand resident taxpayers in receipt of non-investment income is also part of the family assistance programme. In addition to the tax relief provided to low income earning individuals, by way of LIR and the transitional tax allowance, significant financial assistance is also provided to low and middle income earning families with dependent children by way of the Family Support Tax Credit (FSTC), the Independent Family Tax Credit (IFTC) and a Guaranteed Minimum Family Income (GMFI). ${ }^{64}$ Assistance is administered by the Department of Social Welfare (DSW) to welfare beneficiaries, and by the Inland Revenue Department (IRD) to low-income families. ${ }^{65}$ The Family Support Scheme took effect from 1 October 1986 and included the FSTC and GMFI. Depending on circumstances, families may be eligible for both forms of assistance. FSTC function as an income supplement to both working and non-working families, whereas GMFI is not available to those people receiving an income-tested benefit. ${ }^{66}$ The FSTC can be categorised as vanishing credits and the GMFI as a form of work-related subsidy. ${ }^{67}$

61 Above n 58, 51.

62 C March "Financial Assistance to Families in New Zealand" in Scott (above n 11, 115.

63 W R Atkin Social Security Law - Suppl 5, New Zealand (Kluwer Law International, The Hague, 1996), 49.

64 Inland Revenue The New Zealand Tax System (New Zealand Government September, 1996).

65 Above $\mathrm{n} 62,115$.

66 Above n 32, 18-5.

67 J R Kesselman Rate Structure and Personal Taxation: Flat Rate or Dual Rate? (Victoria University Press Wellington, 1990), 58. 


\section{F Low Income Earner Rebate: those people receiving an income-tested benefit.}

From 1 July 1997, the bottom tax rate is reduced to 19.5 cents on the dollar and the threshold separating the bottom and the top tax rates increased to $\$ 38,000$. However, the rebate implies that taxpayers who earn most of their income from employment or selfemployment, and all superannuitants, face a tax scale which effectively has three tax rates 15 cents on the dollar for the first $\$ 9,500$ of income, 21 cents on the dollar for income between $\$ 9,500$ and $\$ 38,000$ and 33 cents on the dollar for income above $\$ 38,000$. The middle effective tax rate is a result of the structure of the LIR. The last year's changes concentrated on reducing the second effective tax rate as this is the rate faced by the majority of low-and middle-income earners. It has been reduced by a total of 7 cents on the dollar over a couple of years. ${ }^{68}$ The rebate can be summarised as an earnings subsidy. ${ }^{69}$

\section{G Family Support Tax Credit}

Families are eligible for FSTC based on the number of dependent children and the combined family income. Entitlement is on a graduated scale. ${ }^{70}$ Where the family income is below specified thresholds (the thresholds change depending on the number of children), the entitlement per child is the maximum amount. However, once the family income exceeds the thresholds, the entitlement gradually decreases for each additional dollar of income, until it is finally extinguished. ${ }^{71}$

The 1997 abatement levels, or income test, which set out how a family's income ${ }^{72}$ affects the annual amount of Family Support, made the full amount of Family Support available when family income is below $\$ 20,000$. It reduces at the rate of 18 cents in the dollar of family income between $\$ 20,000$ and $\$ 27,000$, and by 30 cents in the dollar on family income

68 W Birch, Tax Reduction and Social Policy Programme-Details., (1996), 22-24, and Inland Revenue, (1996).

69 Above n 67, 58 .

70 From 1 July 1997 , FSTC up to $\$ 60$ per week is paid for the eldest child and each additional child aged 16 years or over, up to $\$ 47$ for the first or only child aged under 16 years, up to $\$ 40$ for each additional child over 13 years and up to $\$ 32$ for each additional child under 13 years. (Income Tax Act 1994, s KD2(2).)

71 Birch, above n 68, and March, above n 62, 115.

72 In this context a family's income refers just to the income of the principal caregiver and his or her spouse, if any. The incomes of any other family members, such as the child or grandparents living in the house, are not counted as family income for abatement purposes. (Birch, above n 68, 29) 
above $\$ 27,000$ (which means $\$ 1,260$ plus 30 cents per dollar of specified income exceeding $\$ 27,000) .^{73}$

Although income tax liability is based on individual incomes, the amount of FSTC entitlement is based on spouses' aggregated income. Family Support was previously paid to each spouse in equal shares. However, as of the 1991 income year, two-parent families who are living together no longer have their Family Support entitlement split. The full amount of the tax credit is to be paid to the principal caregiver ${ }^{74}$ of a dependent child. ${ }^{75}$ The definition of "spouse" is wide, and includes "relationships in the nature of marriage", including de facto situations but does not include a separated spouse. ${ }^{76} \mathrm{~A}$ two-step approach is used to determine the family income. Firstly, income is calculated using all the provisions of the Act except those dealing with the tax credits. Secondly, this figure is adjusted under S KD 1 in the Act for certain items which must be added to determine entitlement to family support. ${ }^{7}$

The same amount of family assistance now applies to those both in, and out of, the workforce. When FSTC is delivered through the tax system, the level of FSTC abates once income exceeds a particular income level. Social Welfare beneficiaries entitled to FSTC who have no other significant income receive the full amount of support along with payments from the DSW. ${ }^{78}$ The Family Benefit, a non-taxable universal benefit of $\$ 6$ a week per child, was amalgamated with Family Support in 1991/92 so that all family assistance is now reduced against combined parental income. ${ }^{79}$

\section{H Guaranteed Minimum Family Income}

The GMFI is a tax credit that supplements the incomes of low-wage working families with dependent children, from 1 July 1997 up to a fixed amount of $\$ 290$ after tax per week, or $\$ 15,080$ net annual income.$^{80}$ Family Support is payable on top of this. This means that the GMFI is an "after tax" income guarantee and is delivered in the form of FSTC. In these circumstances it becomes a negative income tax. To qualify for GMFI, a solo parent has to be employed for at least 20 hours a week, and a couple has to have a combined total of at

Income Tax Act 1994, s KD2(4) and Birch, above n 68, 28-29.

The principal caregiver is defined in the Income Tax Act 1994, s OB 1, as the person who has the primary responsibility for the day-to-day care of the child.

March, above n 62, 116.

Income Tax Act 1994, s OB 1, and above n 32, 18-5.

Above n 32, 18-5.

March, above n 62, 115-116.

Above n 54, 137.

Income Tax Act 1994, s KD3(2) and (3) and Birch, above n 68, 30.
} 
least 30 hours a week of employment. ${ }^{81}$ This benefit structure carries a very high marginal tax for additional hours of work in either part-time or full-time weeks. It also taxes increases in the worker's hourly or weekly pay rate in proportion to the weeks worked per year. $^{82}$

\section{Independent Family Tax Credit}

In 1996 a new Independent Family Tax Credit was enacted. IFTC is a credit separate from and additional to the income tax rate reductions and increases in Family Support. The IFCT is a simple, single amount ( $\$ 15 /$ week) per child regardless of age. For eligible families, IFTC is payable in addition to Family Support. The combined amount is subject to the same income test that applies to Family Support. The abatement applies to the Family Support amount first, and then, when that has been exhausted, to the IFTC amount. ${ }^{83}$

Through this credit, an extra reduction in taxes is targeted to low and middle income working families who are supporting children and who are not reliant on substantial assistance from income-tested social security benefits, student allowances, New Zealand Superannuation or the Accident Compensation scheme. The purpose behind the new IFTC was mainly to solve two equity problems. The first problem was based on the opinion that low and middle income families with children face higher maintenance costs than households without dependent children. Maintenance expenses generated by full-time employment erode the margin of income from paid work over benefit income. The introduction of IFTC was expected to ease the tax burden on these families. The other equity problem was based on the fact that the system tended to lock people in, discouraging beneficiary families from seeking economic independence. By introducing the new IFTC together with higher rates of Family Support, the Minister of Finance, Bill Birch, hoped to allow families to earn more income before all their family tax relief is used up ${ }^{84}$ It is questionable to regard this as an equity problem; it is more a question of reducing the negative effects on work incentives created by the system. The ITFC scheme must be analysed from the ideology presented by the incoming National Government in October 1990. The Government's policy was to ensure that those in genuine need have adequate access to government assistance and that those who can make greater provision for their own needs should be encouraged to do so. Self-reliance was a key principle in this context. ${ }^{85}$

81

82

83

84

85

Birch, above n 68, 30 and March, above n 62, 116.

Above n 67, 60 .

Income Tax Act 1994, s KD2(3) and (4).

Birch, above n 68, 31-34.

J Boston "The Decent Society? Essays in Response to National's Economic and Social Policies" Boston, and L Dalziel, (eds), (Auckland, 1992), 6-7. See further J B Bolger, R Richardson, and W F 


\section{J Family Support and the Ability to Pay}

Even if stereotyped in structure, these tax reliefs together with the guaranteed minimum income constitute a much more far-reaching attempt to target low and middle income earners with reduced ability to pay tax caused by high maintenance costs, than would a zero-rate bracket in the tax schedule. How the ability to pay principle has been decisive for the development of this structure is unclear. It is obvious that a fairer distribution of the tax burden has been of central concern when initiating the process of increased targeting. However, it seems as if the general policy of targeting benefits has come to dominate the development. How the combined impact of taxes and benefits on the distribution of income meets the ability to pay tax is still an open question.

\section{NEW TRENDS}

The excessive emphasis on efficiency and excess burden based on the almost dogmatic concept of efficiency provided by the optimal tax analysis have been shown to be a dead end for the design of tax systems. To achieve tax neutrality the optimal tax approach in its extreme stresses the need for selectivity and unequal rate taxation. This is contradictory to the comprehensiveness and uniformity of tax treatment called for in the broad-based and rate flattened income tax and direct or indirect consumption tax structure developed during the last fifteen years. Optimal taxation is therefore no longer seen as a constructive guide to tax policy. ${ }^{86}$

A more modest assessment of potential efficiency gains could therefore be expected in tax reform designs at the end of the 1990s and beyond. With increasing social concern over widening inequality and rising unemployment, it would not be surprising if politicians chose to reintroduce social norms as guiding principles for tax legislation. This could invite a return to an intervening income tax structure and increasing support for progressive income taxation. The domination and content of the horizontal equity principle and neutrality principles will be questioned. Another scenario is a new awareness of the necessity to better co-ordinate tax and social welfare structures in order to get people, especially women, out of the poverty trap ${ }^{87}$ and economic dependency and into the

Birch Economic and Social Initiative., Statements to the House of Representatives, (The Government Wellington, 1990).

86 Above n 1, 37, and A A Tait "Not So General Equilibrium and Not So Optimal Taxation" (1989) US Public Finance, and J G Head "Tax Fairness Principles: A Conceptual, Historical and Practical Review" (1992) 9 Australian Tax Forum, 84-97.

87 The situation where the "the combined effect of income taxation and abatement of benefits for any increase in non-benefit income results in beneficiaries or low income earners receiving little or no additional reward for increased work effort." (E Brashares, and J P Smith "Poverty Traps in New Zealand" (1991) 8 Australian Tax Forum, 63.) 
workforce. ${ }^{88}$ The issue of interface between the tax and benefit systems is of great concern in New Zealand. A lack of integration and consistency have emerged from separate developments concerning tax and income maintenance policies. ${ }^{89}$ Many tax analysts are of the opinion that women are particularly disadvantaged by this lack of consistency, ${ }^{90}$ based on the fact that women are over-represented among the poor in New Zealand and heavily dependent on the state as a provider of transfers and services. Women are also the dominant clients of the Income Support Service. ${ }^{91}$

By the early 1980s, the main part of social expenditure in New Zealand, including education, health care, and some forms of income, was largely non-means-tested. The welfare system had primarily been based on a mixture of the residualist and right-based models. The policy shift from the mid-1980s and forward towards a minimal welfare state with a much more targeted social policy regime - a shift rooted in economic depression and neoliberal winds - initiated a radical restructuring of the welfare state. Implemented first by the fourth Labour Government (1984-1990) and then by the incoming conservative Government, the restructuring has involved significant cuts in income support together with a tightening of eligibility criteria. There has been a move away from universal programmes to a more tightly targeted social assistance system. ${ }^{92}$ During the same period, the Labour Government made radical changes in the tax system: a substantial flattening of the tax rate scale and a greater reliance on indirect taxes with the introduction of a comprehensive VAT. The purpose was to reduce the progression in order to minimise the efficiency costs of high effective marginal tax rates $\left(\mathrm{EMTR}^{93}\right.$ ) as they have a negative effect on work incentives.

\section{A Interface Issues and labour market participation of women}

Personal income tax together with social security contributions, clearly play a predominant role in any how taxation may influence social or economic behaviour. However, it is difficult to establish the relationship between taxation and the incentives to

90

Above n 1, 40, and G B Peters The Politics of Taxation: A Comparative Perspective (Blackwell Cambridge 1991), 289.

9 Above n 54, 135.

See Scott, above $n 11$.

A de Bruin "Implications of the Welfare State and Its Restructuring for New Zealand Women: A Feminist Critique" 172-185, in Scott, above n 11, 173.

Boston above $\mathrm{n} 85$ at 5-6 and De Bruin above $\mathrm{n}$ 91, 172.

"EMTR measure how much of an additional dollar of private income is paid to the government in taxes and/or the withdrawal of income tested benefits, and indicate where poverty traps may occur." Above n 87, 63. 
work. A basic problem for any income tax system, the problem of equal importance for work supply, is the question of what the relative treatment of taxpayers in different working and family situations should be.

A woman's economic independence can be measured by the share of family income, which in turn depends on the cross effects of the participation rate of men and women in the labour market, the number of hours worked, the wage ratios of women relative to men, and taxes and social security contributions. Gustafsson and Bruyn-Hundt point out that women's decisions to enter and remain in the labour market are dependent on whether their work increases family after-tax income above what their household production is worth to the family. Gustafsson and Bruyn-Hundt have determined four important factors in looking at the incentives or disincentives of the tax and the social security systems for women's participation in the labour market. The four factors are the choice of the tax unit (joint or separate taxation), the method of determining income, allowances and deductions, and whether the tax rate is linear, progressive, or regressive. ${ }^{94}$ Some examples of these interface issues, traced in the New Zealand tax and benefit systems, are given below.

\section{B Income}

The definition of income has become important for both the social security system and health benefits as there has been a move away from free health care.

The general definition of income in that area provides that income in relation to any persons: ${ }^{95}$

(a) Means any money received or the value in money's worth of any interest acquired, before income tax, by the person which is not capital (except as hereinafter set out); and;

(b) Includes, whether capital or not and as calculated before the deduction (where applicable) of income tax, any periodical payments made, and the value of any credits or services provided periodically, from any source for income-related purposes and used by the person for income-related purposes; ...

The meaning to be given to income for benefit purposes is wider than the meaning normally ascribed to income for income tax purposes. In a recent case, the Judge weighed the principal features of income recognised in the cases ${ }^{96}$ and the wide ranging definition of

94 S Gustafson, and M Bruyn-Hundt "Incentives for Women to Work: a Comparison between the Netherlands, Sweden and West Germany" (1991) 18 Journal Of Economic Studies, 30-31.

95 Social Security Act 1964, s 3(1).

46 The Judge recognised in this context specially the principles stated in Reid $v$ Commissioner of Inland Revenue [1983] 6 NZTC 61, 624. 
income in the Social Security Act, designed to capture all forms of money used to maintenance of person or family. An important point made by the Judge was that an essential quality of income is when the income truly adds to the resources of the person receiving them. In this respect, loans are disqualified as they are available without regard to need in general terms and must be repaid. The Judge also stated that if Government sees taking out a loan to assist with living expenses as disentitling a student to other needsbased social welfare assistance then it should make that plain by clear legislative expression. ${ }^{97}$ This judgment illustrates that an integrated approach is required if the goal is to create a unified definition of income, especially since family support has become an integrated part of the income tax system. It has not been the ambition of this article to provide comprehensive coverage of all types of income definition in tax and social legislation. Despite its limitations, this study has reviewed, from both a substantial and a technical respect, three ways in which income can be defined - the general definition for tax purposes, the definition of family income used to determine entitlement for family support, and the definition in the Social Security Act.

\section{Unit of Assessment}

In contrast to the tax system, the benefit system in New Zealand has traditionally used the couple as the unit of assessment. Thus ordinary social security benefits, such as sickness, unemployment and invalids' benefits, are paid at a lower rate for married persons than for single persons and are assessed according to joint income. The lower rate implies some economies are possible for married people that are not available to people who simply live together. The income test implies income sharing, as an unemployed woman or man may lose all entitlement to the benefit because of their spouses' income. The amount of income exempt from the social security income test is the same for the married couple as for a single person. According to St John this implies a penal treatment of marriage. ${ }^{98}$ On top of this, to determine what is and what is not a marriage-like situation is notoriously difficult question. The applicant for a benefit must not be "living together with her husband or his wife or with the other parent of the child, as the case may be." 99 The words "husband" and "wife" are given an extended meaning to include those who have been living together in a de facto relationship, understood as a relationship in the nature of marriage. The traditional approach to the existence of a de facto relationship involved proof first of actual cohabitation and, secondly of the mental intention evidenced by such factors, weighted 97 Director-General of Social Security $v$ K \& M Unreported, 7 Feb 1996, High Court, Wellington Registry,
AP 255/95.

Above n 54, 135-136.

99

Social Security Act 1964, Section 27B(2)( c), SSA. 
individually. ${ }^{100}$ A good example of this approach is given in Mauri $v$ Department of Social Welfare. A woman was convicted of making false statements with respect to her relationship with a man who came and went from her home as he pleased. The quality of the relationship was very low, the man often being drunk, and not contributing financially. Without more, the judge might have been inclined to say that the relationship was not in the nature of marriage. However, the woman had also borne the man three children. The court took into account other factors such as the length of the relationship, its degree of permanence, living conditions, the existence of sexual relations, financial arrangements, evidence of commitment to the interests of the other, sharing of leisure time activities, how the couple presented themselves to outsiders, and whether the relationship was exclusive of third persons. ${ }^{101}$ However, recently the Court of Appeal in Ruka v DSW adopted a somewhat new approach when deciding that financial interdependence is an essential element in a relationship in the nature of marriage. ${ }^{102}$

Inconsistency also exists within the tax system. As shown above, the family support scheme is income-tested on a joint income basis. The income test is based on the family as a unit for assessment. The abatement of this type of tax credit therefore does not coincide with the rest of the income tax system which is based on the individual as a unit. This family support scheme means that the tax system contains both individual and joint taxation. It is in conflict with the ability to pay principle. Income testing a substitute for a benefit which was previously universally available will effectively increase the marginal tax rate for the secondary earner in the family. It can be expected that the overall impact of the income test will be to encourage further dependency, as well as an efficiency loss to the economy which is all the greater owing to the special sensitivity of labour supply by secondary earners to marginal tax rates. ${ }^{103}$

\section{EMTR and Family Support}

The targeting regimes counteracted the fourth Labour Government's purpose to reduce progression by introducing an almost pure dual rate tax schedule. It is obvious that the targeted combination of low income rebate, credit on top of credit, and guaranteed minimum income raise effective marginal and average effective tax rates above the $19.5 \%$ basic rate for persons at lower to middle incomes, a significant part of the population. The main sources today of high EMTRs are benefit and Family Support abatement and the GMFI, not

See further W R Atkin, Living Together Without Marriage: The Law in New Zealand (Butterworths, Wellington, 1991) 13-29.

101 (1987) 4 NZFLR 481.

1112 [1997] 1 NZLR 154.

1113 Chan, above $n 11,67$. 
the income tax scale in itself. ${ }^{104}$ In fact, many low income earners face higher average effective tax rates than higher income individuals do. For low income individuals who receive significant net benefits the tax system therefore is regressive. ${ }^{105}$ This shows the tensions between trying to minimise the cost of tax expenditures providing horizontal equity between different sizes of family, providing an adequate minimum income, ensuring vertical equity, and minimising the efficiency costs of high effective marginal tax rates. ${ }^{106}$

The National Government has tried to overcome the EMTR problems. One of the most far reaching proposals was presented by the Change Team on the Targeting of Social Assistance, set up by the Government to design a new and integrated system. The policy document that emerged ${ }^{107}$ was the background paper for the wide-ranging reforms announced in the 1991 budget where two new concepts were introduced, the "core family" and "family accounts". All income support would be based on a single income test, a single income exemption, a single rate and uniform abatement levels. For this global system the core family should be the new unit of assessment. ${ }^{108}$ However, the definition of a family unit could not be translated to a workable practical solution for welfare abatement. In mid1993, it was announced that the work on family accounts had been abandoned. However, implementation of more tightly targeted welfare policies proceeded. ${ }^{109}$

Conclusions made by Inland Revenue predict that the high effective marginal tax rates facing low income earners on benefits reduces the overall efficiency of the tax system, and that the equity implications can be interpreted as such as the EMTRs mean that redistribution in the current family support tax credit regime has become inefficient. Targeting benefits for equity and fiscal cost reasons need, therefore, to be weighed against the potential efficiency costs associated with imposing relatively high effective marginal tax rates on beneficiaries. ${ }^{110}$

It is obvious that the combination of the flattening of income tax rates and an increase of targeted benefits have been disadvantageous for women in their role as secondary earners

Above n 87, 77-78 and above n 67, 58.

Inland Revenue, Supplementary Briefing Paper, Vol 2, (October 1996).

Stephens, above $\mathrm{n} 38,50-51$ and 61.

Change Team on Targeting Social Assistance, Report of the Change Team on Targeting Social Assistance. (Wellington, 1991).

Jenny Shipley et al Social Assistance. Welfare that Works a Statement of Government Policy on Social Assistance (New Zealand Government, Wellington, 1991).

Above n 54, 138-140.

Inland Revenue, Supplementary Briefing Paper, Vol 2, (October 1996). 
in households with dependent children or in their role as solo mothers. The legislators have failed to design an income tax system with a uniform and consistent definition of income. Another inconsistency is that the individual as a unit of assessment is not generally applicable. St John predicts further complexities if the trend of using different definition of incomes for specific targeting measures to reduce gross inequities remains. ${ }^{111} \mathrm{I}$ am prepared to agree. The picture becomes even more complex if one consider that the income tax base is not as comprehensive as would be desirable from an ability to pay perspective. This means that a taxpayer receiving tax relief based on the Family Support scheme may have an untaxed economic capacity derived from income like capital gains. The existing situation suggest that a closer consideration of what and whose ability should be targeted would be a fruitful strategy in future tax reforms.

$111 \quad$ Above $\mathrm{n}$ 54, 135, 140 and 145. 